\title{
ANALISIS KECERDASAN INTRAPERSONAL ANAK DISABILITAS DI TK AISYIYAH 33 SURABAYA
}

\author{
Shihiyah Zuhrita \\ TK Aisyiyah 33 Surabaya \\ Email: shihiyah.zuhrita-2014@fkip.um-surabaya.ac.id
}

\begin{abstract}
ABSTRAK
Kecerdasan intrapersonal adalah kemampuan untuk memahami dan mengendalikan diri dengan baik, sedangkan disabilitas merupakan ketidak sempurnaan seseorang dalam fisik, mental maupun intelektual yang menjadi hambatan bagi orang tersebut untuk melakukan interaksi sosial dengan lingkungan sekitarnya. Tujuan dari penelitian ini adlah untuk mengetahui tingkat kecerdasan intrapersonal anak disbilitas di TK Aisyiyah 33 Surabaya. Rumusan masalah dari penelitian ini adalah menganalisis kecerdasan intrapersonal anak disabilitas di TK Aisyiyah 33 surabaya. Metodologi penelitian yang digunakan dalam penelitian ini adalah kualitatif dengan menjabarkan hasil penelitian secara deskriptif. Teknik pengumpulan data dilakukan dengan cara observasi, wawancara dan dokumentasi. Subjek data dari penelitian ini adalah staff pengajar dan siswa di TK Aisyiyah 33 dengan objek penelitian anak disabilitas di TK Aisyiyah 33. Dari hasil penelitian diketahui bahwa Rara anak disabilitas di sekolah tersebut memiliki kecerdasan intrapersonal yang tinggi, terutama pada kemampuan mengontrol emosi dan kepercayaan diri. Hal ini deisebabkan oleh beberapa faktor yaitu lingkungan dan kemampuan dalam mengenali diri sendiri.
\end{abstract}

Kata kunci: Anak Usia Dini, Disabilitas, Kecerdasan Intrapersonal;

\begin{abstract}
Intrapersonal intelligence is the ability to understand and control ourselves well, whereas disability is an imperfection person in the physical, mental as well as intellectual which becomes obstacle for the person to do social interaction with the surrounding environment. The purpose of this research is to determine the level of intrapersonal intelligence of disable children in Aisyiyah kindergarten 33 Surabaya. The formulation of the problem in this research is to analyze intrapersonal intelligence of children with disability in Aisyiyah Kindergarten 33 Surabaya. The research methodology used in this research is qualitative by describing the research result descriptively. The data collection technique used observation, interview and documentation. Subject from this research is teaching staff and students in Aisyiyah kindergarten 33 with research object of disable children in Aisyiyah kindergarten 33. From research result known that Rara, disable child in school, have high intrapersonal intelligence, especially on ability to control emotion and confidence. This is caused by several factors: the environment and the ability to recognize oneself.
\end{abstract}

Key words: children, dissability, intrapersonal intelegence

\section{PENDAHULUAN}

Pendidikan anak usia dini atau yang biasa dikenal dengan PAUD merupakan masa belajar awal bagi anak, sejak anak lahir hingga usia enam tahun sebelum memasuki jenjang pendidikan dasar. Pendidikan anak usia dini sendiri dapat dilakukan dengan berbagai cara dengan menitikberatkan pada penguatan enam aspek pembelajaran yaitu, perkembangan kognitif, perkembangan bahasa, perkembangan motorik, perkembangan sosial-emosional dan nilai-nilai keagamaan, serta seni. Pendidikan bagi anak usia dini 
sendiri sangat penting peranannya bagi masa depan anak karena pada masa ini merupakan masa emas bagi anak yang biasa kita kenal dengan istilah golden age. Disebut sebagai masa emas karena usia dini merupakan masa kunci dimana pada masa tersebut jaringan otak anak mampu tumbuh dengan pesat bagaikan memori pada komputer yang mampu menyimpan berjuta informasi, dengan pemberian rangsangan yang tepat sesuai dengan tahapan usia dan karakteristik anak yang unik, maka potensi dan bakat yang dimiliki oleh anak akan berkembang dengan baik, walaupun sebenarnya kecerdasan atau intelegensi seseorang sudah dibawa sejak ia dilahirkan.

Berbicara tentang intelegensi, manusia terlahir bukan hanya dengan satu kecerdasan saja melainkan dengan beberapa kecerdasan.Hal ini sejalan dengan pendapat Howard Gardner dalam Asmani (2015:161) bahwa tidak ada satuan kegiatan manusia yang hanya menggunakan satu macam kecerdasan saja melainkan beberapa kecerdasan. Semua kecerdasan bekerja sama membentuk satu kesatuan yang utuh dan terpadu yang kita kenal dengan kecerdasan jamak. Kecerdasan jamak pada anak dapat dikembangkan sedari dini. Setiap anak adalah unik dan menyimpan banyak potensi. Setiap aspek tahapan perkembangan anak seperti, fisik, bahasa, social, emosional, seni dan kognitif secara langsung berkaitan erat dengan perkembangan kecerdasan jamak ini.
Tugas kita sebagai seorang pendidik adalah menstimulasi, memotivasi, mengarahkan, memfasilitasi, dan membimbing, agar mereka mampu mengembangkan berbagai macam potensi dan kecerdasan jamak pada anak. Proses pembelajaran yang menyenangkan dapat menarik minat anak untuk aktif dalam kegiatan yang diberikan oleh pendidik sehingga perkembangan kecerdasan anak dapat dikembangkan secara optimal.

Salah satu dari kecerdasan jamak adalah kecerdasan intrapersonal, yaitu Kecerdasan intrapersonal merupakan kecerdasan yang terletak pada diri seseorang yang ditandai dengan kemampuan untuk memahami diri sendiri, dan bertindak berdasarkan pemahaman tersebut. Kemampuan yang dimaksudkan adalah kemampuan untuk mengenali kelebihan pada diri, kekurangannya, keterbatasan diri, kecerdasan terhadap emosi atau suasana hati, keinginan, motivasi, maksud dan tujuan, juga mampu menghargai diri, mengendalikan diri. Kemampuan ini juga meliputi kemampuan untuk menganalisis diri sendiri, tahu dengan baik tentang dirinya sendiri, apa yang diinginkan, apa yang akan dilakukan, apa yang terbaik bagi dirinya, bagaimana memberikan respon terhadap situasi tertentu, dan menyikapinya dengan baik, serta intropeksi diri.

Pemahaman diri ini sangat baik untuk membantu seseorang mengembangkan potensi dalam dirinya dan membantunya untuk dapat mengekspresikan diri dengan 
lebih baik, dan mampu berkarya secara optimal. Kecerdasan intrapersonal memiliki manfaat yaitu membangun citra diri dan harga diri, mengendalikan emosi, mampu bertanggungjawab pada diri sendiri Pada kenyataannya kebanyakan anak usia dini kurang memahami dirinya sendiri. Sering kita jumpai seperti yang saya temukan di TK Aisyiyah 33.Anak yang antusias di awal pembelajaran, namun ketika diberikan tugas atau kegiatan main antusias mereka hilang. Juga ketika diberikan kegiatan seperti menulis, atau mewarnai setelah bebrapa menit anak merasa capek dan malas, tak jarang bahkan anak berkata tidak mampu mengerjakan bahkan sebelum ia mencoba. Selain itu di TK Aisyiyah 33 ada anak penyandang disabilitas yang memiliki kemauan tinggi namun, setelah beberapa kali mencoba ia kembali diam merasa tidak mampu untuk menyelesaikan, bahkan seringkali menangis. Oleh karena itu kecerdasan intrapersonal penting untuk dikembangkan sebagai upaya agar anak mampu memahami seluk beluk tentang dirinya untuk mengekspresikan diri dengan lebih baik.Kecerdasan intrapersonal pada anak dipengaruhi oleh kemauan anak dalam mengembangkan diri dan

HASIL PENELITIAN

Berdasarkan Pengamatan yang dilakukan pada November 2017 sampai desember 2017 maka, motivasi dari lingkungan sekitar anak. Selain itu kegiatan belajar dan media pembelajaran yang digunakan serta cara guru dan orang tua dalam membimbing anak untuk mengenali diri sendiri memiliki pengaruh dalam proses pengembangan kecerdasan intrapersonal pada anak, terutama bagi anak disabilitas.

\begin{tabular}{lcr}
\multicolumn{2}{c}{ Berdasarkan } & permasalahan di \\
atas maka & peneliti ingin \\
menggambarkan & \multicolumn{2}{c}{ kecerdasan } \\
intrapersonal & seorang & anak \\
penyandang disabilitas di & TK
\end{tabular}
Aisyiyah 33 Surabaya. adapun tujuan dari dilakukannya penelitian ini adalah Untuk mengetahui kecerdasan Intrapersonal anak disabilitas di TK Aisyiyah 33 Surabaya.

\section{METODE PENELITIAN}

Jenis penelitian yang digunakan dalam penelitian ini adalah penelitian kualitatif. sumber data dari penelitian ini adalah hasil wawancara dari staff pendidik yang berjumlah 3 orang serta hasil dari observaasi yang dilakukan selama penelitian. Sedangkan objek dari Penelitian ini adalah anak perempuan penyandang disabilitas berusia 6 tahun kelompok B di TK Aisyiyah $33 . \quad$ Teknik pengumpulandata yang digunakan adalah Observasi.

diperoleh data kecerdasan intrapersonal Rara, anak disabilitas di TK Aisyiyah 33 Surabaya sebagai berikut : 
Tabel 4.3

Kecerdasan Intrapersonal Anak Disabilitas di TK Aisyiyah 33 Surabaya.

\begin{tabular}{|c|l|c|c|c|c|}
\hline \multirow{2}{*}{ No. } & \multicolumn{1}{|c|}{ Butir } & \multicolumn{3}{|c|}{ Penilaian } \\
\cline { 3 - 6 } & \multicolumn{1}{|c|}{\begin{tabular}{l}
\multicolumn{1}{|c|}{} \\
Anak Mau bermain bersama teman- \\
temannya
\end{tabular}} & & & & V \\
\hline 2. & Anak Berani Maju kedepan kelas & & & V & \\
\hline 3. & Anak mampu melakukan semuanya sendiri & & & V & \\
\hline 4. & $\begin{array}{l}\text { Anak mampu menentukan barang yang } \\
\text { disukai }\end{array}$ & & $\mathrm{V}$ & & \\
\hline 5 & $\begin{array}{l}\text { Anak mampu memilih kegiatan bermain } \\
\text { yang disukai }\end{array}$ & & $\mathrm{V}$ & & \\
\hline 6 & $\begin{array}{l}\text { Anak mampu menyelesaikan tugas tepat } \\
\text { waktu }\end{array}$ & & & $\mathrm{V}$ & \\
\hline 7 & Anak tidak mudah marah ketika terusik & & & & $\mathrm{V}$ \\
\hline
\end{tabular}

kecerdasan intrapersonal anak disabiilitas di TK Aisyiyah 33 Surabaya maka dapat dijelaskan sebagai berikut:

1. Anak mau bermain dengan teman temanya

Rara ketika di sekolah mampu mengatasi rasa kurang percaya dirinya.Ia suka bersosialisasi dengan teman temannnya. Ia bahkan mengajak temannya untuk bermain bersama. Walaupun gerak tubuhnya terbatas ia tetap dapat membaur dengan teman temannya yang lain.ia tidak segan menyapa atau meminta bantuan pada temannya untuk mengambilkan mainan yang dia inginkan. Terkadang ia juga ikut serta dalam permainan berkelompok seperti masakmasakan dengan teman teman sekelasanya. (LO1; CW5; D1)
2. Anak berani tampil di depan kelas

Rara walaupun ia selalu percaya diri saat bermain, berbeda ketika kegiatan belajar. ia masih butuh didampingi oleh guru kelas untuk tampil solo di depan kelas. Ketika guru kelas meminta rara untuk menyanyikan sebuah lagu yang baru saja diperdengarkan ia enggan untuk menyanggupi, sampai akhirnya guru kelasnya berusaha meyakinkan dirinya barulah kemudian ia maju kedepan menyanggupi permintaan gurunya tentusaja dengan dibantu oleh guru kelasnya karena Rara tidak bisa berjalan sendiri. Rasa percaya dirinya luntur ketika berdiri sendiri menghadapi temannya didepan kelas, walaupun begitu ia tetap memberikan 
penampilannya. (LO2; CW4; D2)

3. Anak mampu melakukan semuanya sendiri

Rara meskipun ia seorang disabilitas tetapi ia tidak hanya mengandalkan bantuan orang lain untuk mengurus kebutuhannya. Seperti ketika makan ia mengambil makananannya sendiri, membuka dan mengemasi kembali tempat makan atau minum yang suda digunakan. Bahkan ia tidak lupa membuang sampah bekas makanannya di tempat sampah yang diisediakan. Ia bahkan mampu menaiki perosotan sendiri tanpa bantuan orang lain. Walaupun untuk urusan buang air ia masih butuh bantuan dari gurunya. (LO3; CW7; D3)

4. Anak mampu memilih benda kesukaannya

Rara, seperti yang dapat dilihat pada tabel di atas bahwa ia belum mampu menentukan pilihan ia masih membutuhkan guru untuk membantunya dalam memilih buku yang ingin dibaca. Seperti kata guru kela Rara ia masih belum mampu mencocokkan atau memilih mana gambar yang menunjukkan sifat terpuji atau tercela. Dalam menentukan pilihan sendiri Rara masih kurang mampu, terkadang ia masih ikut ikutan temannya dalam membuat pilihan. Terkadang ia tergoyahkan oleh saran dari teman-temannya. (LO4; CW4; D4)

5. Anak mampu menentukan kegiatan bermain yang disukai

Seperti yang telah dijelaskan pad point sebelumnya Rara masih belum mampu membuat pilihan, atau mengambil keputusan. Bahkan dalam menentukan kegiatan bermain yang disukai ia masih mengikuti pilihan temantemannya. Terkadang Rara hanya menunggu temannya memilih terlebih dahulu baru kemudian sisanya adalah miliknya. Karena ruang gerak yang terbatas mainan yang ia suka telah dipakai oleh temannya sehingga ia harus menunggu dan mengambil mainan yang tidak dipilih oleh temannya untuk dimainkan. (LO5, CW8; D5)

6. Anak mampu mengerjakan tugas tepat waktu

Rara selalu menyelesaikan tugasnya namun, ia selalu melebihi batas waktu yang telah ditentukan oleh guru kelasnya. Ketika mengerjakan tugas ia sedikit lambat karena selain kakinya yang menyulitkannnya untuk bergerak bebas, otot tangannya juga kurang lemas sehingga menghambat waktu penyelesaian tugas. Ia juga sesekali berbicara atau sekedar bertanya pada teman sebangkunya atau membandingkan tugasnya 
dengan teman sebangkungnya. (LO6; CW;9 D6)

7. Anak tidak marah ketika terusik

Rara adalah anak yang pendiam ia tidak pernah marah bahkan sesering apapun temannya menggangu ia hanya diam saja, kecuali ada yang mengejek tentang fisiknya ia akan menangis atau ketika pukulan yang diberikan oleh temannya terlalu sakit ia baru akan bereaksi, seperti membalas atau menangis keras keras. (LO7; CW9; D7)

Berdasarkan butir penilaian yang telah dijabarkan denga jelas di atas, dapat dipastikan kesesuaiannya pada tabel triangulasi di bawah ini

Triangulasi Data

\begin{tabular}{|c|c|c|c|c|}
\hline No. & Butir Penilaian & $\begin{array}{l}\text { Lembar } \\
\text { Observasi }\end{array}$ & $\begin{array}{c}\text { Catatan } \\
\text { Wawancara }\end{array}$ & Dokumentasi \\
\hline 1 & $\begin{array}{l}\text { Anak Mau bermain } \\
\text { bersama teman- } \\
\text { temannya }\end{array}$ & LO1; LO10 & $\begin{array}{l}\text { CW1.5; } \\
\text { CW2.5; CW } \\
3.5\end{array}$ & $\begin{array}{c}\text { D1, D2, D10, } \\
\text { D13 }\end{array}$ \\
\hline 2 & $\begin{array}{l}\text { Anak Berani Maju } \\
\text { kedepan kelas }\end{array}$ & LO2 & $\begin{array}{l}\text { CW 1.4; } \\
\text { CW2.4; } \\
\text { CW3.4 }\end{array}$ & D9 \\
\hline 3 & $\begin{array}{l}\text { Anak mampu } \\
\text { melakukan semuanya } \\
\text { sendiri }\end{array}$ & LO3; LO9 & $\begin{array}{l}\text { CW 1.7; CW } \\
2.7 ; \text { CW } 3.7\end{array}$ & $\begin{array}{l}\text { D5; D3; D;7 } \\
\text { D8; D13 }\end{array}$ \\
\hline 4 & $\begin{array}{l}\text { Anak mampu } \\
\text { menentukan barang } \\
\text { yang disukai }\end{array}$ & LO4; LO 8 & $\begin{array}{l}\text { CW 1.4; CW } \\
2.4 ; \text { CW } 3.7\end{array}$ & D1; D2 \\
\hline 5 & $\begin{array}{l}\text { Anak mampu memilih } \\
\text { kegiatan bermain yang } \\
\text { disukai }\end{array}$ & LO 5 & $\begin{array}{l}\text { CW 1.8; CW } \\
2.8 ; C W 3.8\end{array}$ & D13 \\
\hline 6 & $\begin{array}{l}\text { Anak mampu } \\
\text { menyelesaikan tugas } \\
\text { tepat waktu }\end{array}$ & LO 6 & $\begin{array}{l}\text { CW 1.9; CW } \\
2.9 ; \text { CW } 3.9\end{array}$ & $\begin{array}{c}\text { D3; D4;D11; } \\
\text { D12 }\end{array}$ \\
\hline 7 & $\begin{array}{l}\text { Anak tidak mudah } \\
\text { marah ketika terusik }\end{array}$ & LO 7 & $\begin{array}{l}\text { CW 1.9; CW } \\
2.9 ; \text { CW } 3.9\end{array}$ & D2; D12 \\
\hline
\end{tabular}

\section{PEMBAHASAN}

Penelitian ini dimulai pada bulan November sampai desember 2017 di TK Aisyiyah 33. Subjek penelitian ini adalah seorang anak perempuan berusia 6 tahun.Ia adalah seorang disabilitas atau anak yang memiliki kekurangan (cacat tubuh). Namanya adalah Rara. Sekilas ia terlihat seperti anak normal ketika sedang duduk diam, namun ketika berdiri ia harus bertumpu pada sesuatu. Cacat fisik/ disabbilitas yang dideritanya adalah kakinya tidak bisa 
digunakan untuk berjalan. Menurut keterangan dari kepala TK dan Staff pengajar di TK Aisyiyah 33 ia menderita disabilitas tersebut bukan sejak dia lahir melainkan karena terjadi sebuah kecelakaan saat ia masih kecil dulu. Rara terjatuh dan kemudian terjadi sesuatu pada otot kakinya sehingga sulit digerakkan.Kakinya juga tak cukup kuat untuk menopang berat badannya.Walaupun bentuk kaki dan ukurannya terlihat normal namun tetap saja tidak dapat berfungsi dengan semestinya. Menurut hasil pengamatan selama penelitian selain cacat fisik yang dideritanya tidak ada kecacatan lainnya lagi, bahkan ketika berada didalam kelas ia juga belajar layaknya anak seusianya. Rara ikut bernyanyi, bertepuk, bahkan bergerak sesuai irama lagu namun hanya bagian tubuh atas yang bergerak. Ia juga sama antusiasnya dengan teman sekelasnya ketika belajar, ia dapat menghafal do'a do'a harian dan surat pendek ia juga mampu membaca iqro'(hijaiyah). Di dalam kelas Rara selalu duduk diam memperhatikan guru ketika mengajar.Ia juga selalu mengerjakan tugas yang diberikan oleh guru walaupun seringkali melebihi waktu yang telah ditetapkan. Sekalipun ia terlambat dalam menyelesaikan tugasnya ia tetap mengerjakannya sampai tuntas.

Ketika waktu istirahat, Rara juga mampu mengurus dirinya dengan baik.Ia mampu memenuhi kebutuhannya sendiri seperti makan, minum. Ia mampu membuka tempat makan dan minum yang telah dibawa daari rumah sendiri tanpa dibantu baik teman maupun gurunya. Ia juga mau membuang sampah bekas kue atau minuman yang dia nikmati saat istirahat di tempat sampah dengan cara berjalan menggunakan lututnya. Ia juga tidak seganuntuk bergabung bersama temannya bermain bersama. Naik perosotan atau hanya sekedar bercengkrama, bertukar cerita tentang barang kepunyaan atau warna favorit atau permainan Favorit.Sebagai anak disabilitas Rara merupakan seorang yang madiri dan penuh percaya diri.Ia tidak pernah menutup diri dari lingkungan sosialnya. Walau tidak semua hal bisa ia lakukan sebagai seorang disabilitas seperti ketika akan buang air baik kecil maupun besar ia masih butuh bantuan dari guru. Juga ketika memakai celana sehabis buang air ia masih perlu dibantu.

Rara terlihat sangat mengenal dirinya sendiri.Ia ahu apa yang dia inginkan, seperti buku bacaan yang ia suka, warna yang ia pakai untuk mewarnai gambar di LKA (Lembar Kerja Anak), atau lagu yang ingin dinyanyikan ia tau semuanya. Terkadang ia juga ikut-ikutan temannya ketika memilih warna untuk mewarnai gambar di LKA (Lembar Kerja anak). Ketika bermain juga terkadang ia yang memilih permainan yang dimainkan dan mengajak teman temannya ikut serta atau ia menunggu temannnya mengajakknya bermain atau sekedar memainkan mainan yang tersisa dari teman sekelasnya. Rara juga pandai 
dalam mengontrol emosi.Hal inilah yang membedakan Rara dengan anak disabilitas lainnya. Pada umumnya anak disabilitas memiliki ciri yaitu ketidak seimbangan emosi dalam arti mereka kurang mampu mengendalikan emosi yang menyenangkan dan tidak menyenangkan secara seimbang (Asyari:17). Seperti ketika temannya datang mengganggu atau mengolokolok dirinya ia tidak serta merta marah atau membalas temannya. Dia hanya diam saja seperti menahan diri agar tidak meledak marah. Juga saat ia dipukul oleh temannya ia tidak akan memukul balik. Kecuali jika sakit maka ia akan menangis dan melaporkannya pada guru yang mengajar. Ketika merasa senang pun ia tidak menunjukkan reaksi yang berlebihan. Ia hanya tersenyum, tidak pernah sampai tertawa terbahak-bahak. Begitu juga ketika merasa kurang enak badan ia hanya diam saja baru ketika ditanya guru kenapa ia diam, ia akan mengungkapkan kalau ia kurang enak badan.

Hal ini disebabkan oleh lingkungan tempat ia belajar menanamkan toleransi emosiaonal yang tinggi. Anak selalu dibiasakan untuk saling tolong menolong dan tidak bersifat merendahkan. Mereka selalu diajarkan untuk menganggap semua temannya adalah sama apapun kondisinya. Bahkan ketika bermain anak selalu diajarkan untuk berbagi, bergantian, dan saling menjaga satu sama lain sehingga tidak ada yang merasa terkucilkan. Selain itu Rara

sendiri memiliki kontrol terhadap perasaannya sendiri.

Dari gambaran tentang keseharian Rara disekolah maka dapat dikatakan bahwa Rara memiliki kecerdasan intrapersonal. Yaitu kecerdasan dlam memahami diri yang meliputi Rasa Percaya diri, Kemandirian, Pengetahuan akan diri seperti keinginan dan prioritas serta kontrol dalam emosi. Pernyataan ini sesuai denganapa yang di ungkapkan oleh suyadi (2010:174) bahwa anak dengan kecerdasan intra personal memiliki ciri-ciri yaitu memiliki rasa percaya diri yang tinggi, mengetahui apa yang diinginkan, mengetahui apa yang penting dan memahami emosi diri. Dengan kecerdasan Intrapersonal ini Rara terlihat lebih percaya diri dan ia mampu mengatasi kekurangannya dengan belajar memahami diri dan mencari jalan keluar dari permasalahan yang ia hadapi yaitu kesulitannya dalam bergerak. Ia mampu memanfaatkan bagian tubuh lainnya yang bisa digunakan untuk membantu memudahkannya dalam melakukan aktivitasnya sehari hari seperti belajar, dan bermain.

Berdasarkan pengamatan
yang dilakukan oleh peneliti
kecerdasan intrapersonal Rara dapat
berkembang dengan baik karena
dipengaruhi oleh faktor Lingkungan
sekolah yang menerima keadaan dan
mendukung perkembangan Rara
dengan memberikan motivasi supaya
Rara memiliki rasa percaya
diri.Seringkali keadaan Rara sebagai
penyandang disabilitas menarik rasa


empati dari teman-teman sekelasnya, sehingga tidak jarang Rara mendapatkan bantuan dari temantemannya. Cacat fisik yang terdapat pada kaki Rara sering menimbulkan anggapan bahwa Rara tidak akan mampu melakukan aktivitas yang menggunakan kekuatan kaki, namun hal tersebut dapat ditepis dengan pencapaian perkembangan Rara yang semakin hari semakin baik. Rara dapat berkembang demikian karena ruang kelas Rara berada dilantai 2 sehingga ia dapat melatih kekuatan otot kakinya bahkan Rara sekarang dapat menaiki Perosotan sendiri.

Kecerdasan intrapersonal Rara mampu berkembang dengan baik karena terapi bermain yang dilakukan oleh guru sejak Rara mulai masuk di TK Aisyiyah 33 Surabaya.Terapi bermain yang dilakukan secara bertahap dan terus menerus ternyata berhasil dalam mengembangkan kecerdasan intrapersonal Rara, sehingga Rara dapat mengenali dirinya dengan baik.

\section{KESIPULAN}

Berdasarkan hasil penelitian terhadap kecerdasan intrapersonal anak disabilitas di TK Aisyiyah 33 dapat ditarik kesimpulan bahwa Rara subjek dari penelitian ini memiliki kecerdasan intrapersonal yang tinggi. Hal ini berdasarkan pada ciri-ciri anak yang meiliki kecerdasan intrapersonal yaitu memiliki rasa percaya diri yang tinggi, mengetahui apa yang diinginkan, mengetahui apa yang penting dan memahami emosi diri. Berbeda dengan kebanyakan anak disabilitas pada umumnya yang memiliki banyak permasalahan seperi kontrol diri terutama emosi yang tidak seimbang, Rara justru sebaliknya memiliki kontrol diri yang sangat baik karena lingkungan tempat belajar yang baik serta orang orang yang selalu mendukung dan kemampuannya dalam mengenal diri sendiri dengan baik. Kemampuannya dalam menentukan pilihan sudah mulai berkembang namun rasa percaya dirinya semakin meningkat.

\section{DAFTAR PUSTAKA}

Asmani, J, M. (2015).Panduan Praktis ManajemenMutu Guru Paud. Yogyakarta: Diva Press.

Jamine, J. (2007). Mengajar Dengan Metode Kecerdasan Majemuk Implementasi Multiple Intellegences, Bandung: Penerbit Nuansa.

Maftuhin, Arif. (2017). Mengikat Makna diskriminasi: Penyandang Cacat, Difabel danPenyandang Disabilitas (Online). Retrieved from: https://www.researchgate.net/ publication/318821497. Nove mber 30 2017. Yogyakarta: Universitas Islam Negeri Sunan Kalijaga.

Moleong, Lexy J. (2012).Metodologi Penelitian Kualitatif. Bandung: Remaja Rosdakarya.

Mubasyaroh. (2015). Pendidikan Bagi Penyandang Disabilitas dan Anak Berkesulitan Belajar: Analisis Penanganan 
Berbasis Bimbingan

Konseling Islam (Online).

Retrieved from:

http://journal.stainkudus.ac.id

/index.php/elementary/article/

view/1453.Desember $\quad 30$

2017.Kudus: STAIN

Putra \& Dwilestari. (2012).

Penelitian Kualitatif

Pendidikan Anak Usia Dini.

Jakarta: Rajawali Pers.

Putranto, Bambang (2015). Tips

Menangani Siswa yang

Membutuhkan Perhatian

Khusus. Yogyakarta: Diva

Press

Setyowati, H. (2014). Aku Anak

Cerdas, Jakarta: Anggota

IKAPI.

Soefandi \& Ahmad (2015).Strategi

Mengembangkan Potensi

Kecerdasan Anak, Jakarta:

Bee Media.

Sugiyono.(2012). Metode Penelitian

Kombinasi (Mixed Method).

Bandung: Alfabetha.

Yaumi, Muhammad. (2012).

Pembelajaran Berbasis Multiple

Intelegence. Jakarta: PT. Dian

Rakyat. 